Tomasz Czapiewski

Uniwersytet Szczeciński

\title{
Regulacja w celu deregulacji. Polityka bezpieczeństwa na obszarach wodnych w Polsce
}

DOI: $10.19195 / 1643-0328.21 .11$

Słowa kluczowe: polityka publiczna, bezpieczeństwo wewnętrzne, proces polityki, utonięcia

\section{Wprowadzenie}

Ustawa z dnia 18 sierpnia 2011 r. o bezpieczeństwie osób przebywających na obszarach wodnych była pierwszym aktem prawnym tej rangi poświęconym wyłącznie zagadnieniu bezpieczeństwa obszarów wodnych, a zarazem krokiem reformującym dotychczas istniejący podsystem oparty głównie na rozporządzeniach oraz dominującej pozycji Wodnego Ochotniczego Pogotowia Ratunkowego (WOPR). Celem niniejszego artykułu jest analiza funkcjonowania tego wycinka polityki publicznej po czterech pełnych latach obowiązywania nowej ustawy. Ujęte w tytule pojęcie polityki rozumiane jest tu szeroko jako „określony sposób postępowania władz publicznych w celu rozwiązania problemów o znaczeniu zbiorowym” oraz „działania - lub ich brak - które wywierają wpływ na życie obywateli"1.

Można odnieść wrażenie, że bezpieczeństwo na obszarach wodnych, czy pisząc precyzyjniej - bezpieczeństwo osób korzystających z obszarów wodnych, traktowane jest jako specyficzny obszar bezpieczeństwa o nie do końca uświadomionym znaczeniu zarówno przez administrację publiczną, jak i świat nauki. Być może ma to związek z brakiem wyznaczonej do tego obszaru służby lub instytucji publicznej. Wpływ mogą też mieć skojarzenia $\mathrm{z}$ beztroską wypoczynku wakacyjnego oraz silne konotacje popkulturowe wytworzone przez amerykańskie seriale telewizyjne ${ }^{2}$. Podejście takie, zdaniem autora tego artykułu, nie jest uzasadnione.

${ }^{1}$ R. Chrabąszcz, M. Zawicki, Nauki o polityce publicznej, [w:] Wprowadzenie do nauk o polityce publicznej, red. M. Zawicki, Warszawa 2013, s. 38.

2 Znamienny jest tytuł artykułu opisującego zawód ratownika wodnego, który ukazał się na portalu skierowanym do licealistów i studentów w ramach serwisu gazeta.pl: Być jak David Hasselhoff $i$ Pamela Anderson, bit.ly/1UaBvyi (dostęp: 31.01.2016). 
W ramach prac nad niniejszym artykułem dokonano analizy źródeł wtórnych - literatury naukowej, aktów prawnych, ich projektów, protokołów posiedzeń organów kolegialnych, raportów, także tych uzyskanych w drodze dostępu do informacji publicznej od Ministerstwa Spraw Wewnętrznych oraz jednostek samorządu terytorialnego. Przeprowadzono również analizę źródeł pierwotnych — pogłębionych wywiadów indywidualnych, które autor artykułu zrealizował od 8 sierpnia 2015 r. do 15 stycznia 2016 r. z pięcioma osobami pracującymi w obrębie szeroko rozumianego sytemu bezpieczeństwa obszarów wodnych. W skład tego grona wchodzili: dwaj ratownicy WOPR na stanowiskach kierowniczych, dwaj urzędnicy samorządowi w gminie i województwie z licznymi obszarami wodnymi oraz ratownik z innego podmiotu niż WOPR, również wykonujący zadania zarządcze. Wywiady te miały charakter dopełniający, polegający głównie na zebraniu doświadczeń osób zaangażowanych $\mathrm{w}$ funkcjonowanie systemu i weryfikacji hipotez postawionych na bazie badania źródeł wtórnych. W kilku miejscach pozwoliły także na wskazanie nowych kierunków analizy, które zostały później uzupełnione przy użyciu innych narzędzi.

\section{Skala problemu utonięć w Polsce}

Często nie dostrzega się faktu, że utonięcia należą do najpowszechniejszych zarówno na świecie, jak i w Polsce przyczyn tzw. śmierci gwałtownej. Szacuje się, że rocznie $\mathrm{z}$ tego powodu życie tracą 372 tys. osób ${ }^{3}$. W Polsce wagę problemu utonięć obrazowo ukazuje statystyka z całego 2014 r. - na terenie kraju doszło do 646 utonięć na obszarach wodnych. Dla porównania policja odnotowała w ciągu tego samego okresu 532 zabójstwa ${ }^{4}$. Problem ten jest w Polsce bardziej dotkliwy niż w innych krajach Unii Europejskiej (UE). Średnia roczna śmiertelnych utonięć w najgorszych latach zbliżała się do 2,0 na 100000 mieszkańców, podczas gdy w innych krajach UE wartość wskaźnika często znajduje się w granicach $0,4-0,6^{5}$. Wyjaśnienie warto uzupełnić poprzez przytoczenie doniesień $z$ Holandii — w latach 2013-2015 tonęło tam średnio ok. 20 osób rocznie, z czego ponad 25\% to Polacy, co stanowi wyraźną nadreprezentację wobec skali polskiej emigracji do tego kraju. Może to wskazywać na duży negatywny wpływ czynników na poziomie wzorów postępowań - brak umiejętności pływania, brak zwyczajowej ostrożności nad wodą wzmocniony w wielu przypadkach nadużywaniem alkoholu ${ }^{6}$.

3 World Health Organization, „Global report on drowning. Preventing a leading killer”, Genewa 2014, s. 3.

${ }^{4} \mathrm{http} / / /$ statystyka.policja.pl/st/wybrane-statystyki/ (dostęp: 30.01.2016).

5 A. Stanula et al., Ilościowa oraz przyczynowa analiza wypadków utonięć w Polsce w latach 2005-2014, [w:] Stan, perspektywy i rozwój ratownictwa, kultury fizycznej i sportu w XXI wieku, red. M. Napierała, A. Skaliy, t. 1. Ratownictwo, Bydgoszcz 2015, s. 167-168.

${ }^{6}$ Utonęło już 9 osób. Ludzie ignorują ostrzeżenia, http://bit.ly/29K85qX (dostęp: 30.01.2016); Utonięciami Polaków żyje cała Holandia [list], „Gazeta Wyborcza” 7.08.2013; Holenderskie media: dlaczego ci Polacy tak toną?, http://bit.ly/29qWIOR (dostęp: 16.12.2015). 
Warto zauważyć, że ponad $80 \%$ utonięć ma miejsce w województwie zamieszkania tonącego, a aż $24,6 \%$ ofiar stanowiły osoby będące pod wpływem alkoholu — przy czym w ok. 40\% badanych przypadków policja nie określiła stanu trzeźwości tonących, więc odsetki te w rzeczywistości mogą być wyższe. Grupę wysokiego ryzyka stanowią mężczyźni w wieku 45-59 lat, szczególnie $\mathrm{z}$ wykształceniem zasadniczym zawodowym ${ }^{7}$. Analizując szczegółowe dane dotyczące utonięć w latach 2010-2014, można zauważyć, że miały one miejsce głównie w następujących obszarach: rzeka, jezioro i staw. Utonięcia w morzu stanowią mniej niż 5\% wszystkich przypadków. Najczęstsze okoliczności wypadków utonięcia to: kąpiel w miejscu niestrzeżonym, lecz nie zabronionym, kąpiel w miejscu zabronionym, nieostrożność podczas łowienia ryb lub nieostrożność podczas przebywania nad wodą ${ }^{8}$. Tabela 1 ukazuje, że w odróżnieniu od innych kategorii przyczyn śmierci gwałtownej w ciągu ostatnich 15 lat w Polsce nie zanotowano poprawy w kwestii zapobiegania utonięciom. Pozytywny trend w pierwszej dekadzie XXI wieku został, niestety, zrównoważony przez drastyczne pogorszenie w pierwszych latach po wejściu w życie ustawy.

Tabela 1. Zdarzenia zakończone zgonem w podziale na kategorie w Polsce w latach 2001-2014

\begin{tabular}{c|c|c|c|c}
\hline Rok & Samobójstwa & Wypadki drogowe & Utonięcia & Zabójstwa \\
\hline 2001 & 6165 & 5534 & 675 & 1325 \\
\hline 2002 & 6101 & 5827 & 741 & 1188 \\
\hline 2003 & 4177 & 5640 & 564 & 1039 \\
\hline 2004 & 3839 & 5712 & 583 & 980 \\
\hline 2005 & 4087 & 5444 & 564 & 837 \\
\hline 2006 & 4384 & 5243 & 479 & 816 \\
\hline 2007 & 3964 & 5583 & 452 & 848 \\
\hline 2008 & 3530 & 5437 & 468 & 759 \\
\hline 2009 & 4090 & 4572 & 369 & 763 \\
\hline 2010 & 4621 & 3907 & 396 & 680 \\
\hline 2011 & 4893 & 4189 & 449 & 662 \\
\hline 2012 & 4634 & 3571 & 760 & 582 \\
\hline 2013 & 5100 & 3357 & 674 & 574 \\
\hline 2014 & 4971 & 3202 & 526 \\
\hline
\end{tabular}

Źródło: Opracowanie własne na podstawie danych uzyskanych z Krajowego Systemu Informacyjnego Policji.

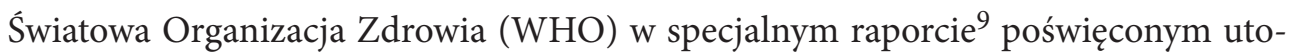
nięciom wskazała na to, że zapobieganie powinno opierać się na dziesięciu działaniach

7 R. Halik et al., Wypadkowe utonięcia w Polsce w latach 2000-2012, „Przegląd Epidemiologiczny” 68, 2014, s. 591-594.

8 http://statystyka.policja.pl/st/wybrane-statystyki/utoniecia/ (dostęp: 30.01.2016).

9 World Health Organisation, „Global report...”, s. 32-54. 
(podzielonych na dwie kategorie - nakierowanych na społeczności lokalne i nakierowanych na politykę państwa i legislację), do których należą:

1. Instalowanie barier ograniczających dostęp do wody;

2. Organizowanie placówek dla dzieci w wieku przedszkolnym w większej odległości od zbiorników wodnych;

3. Nauka dzieci w wieku szkolnym w zakresie pływania, bezpieczeństwa nad wodą i bezpiecznego udzielania pomocy;

4. Szkolenie obywateli w zakresie bezpiecznego udzielania pomocy i resuscytacji;

5. Zwiększenie świadomości społecznej na temat utonięć, z podkreśleniem podatności dzieci na ten typ zagrożenia;

6. Ustalenie i egzekwowanie regulacji dotyczących bezpiecznego użytkowania obiektów pływających;

7. Ograniczenie zagrożenia powodziowego i minimalizowanie jego skutków;

8. Koordynacja działań prewencyjnych w kwestii utonięć pomiędzy instytucjami i organizacjami;

9. Przygotowanie narodowego planu bezpieczeństwa wodnego;

10. Przeprowadzenie dobrze zaprojektowanych badań naukowych w wybranych kwestiach dotyczących utonięć (np. jak efektywnie nauczać pływania, jak skutecznie przekonywać do bezpiecznych zachowań, jak wykorzystywać nowoczesne środki łączności w systemach ostrzegania).

Uważa się też, że jakość zabezpieczenia ratowniczego jest jednym z najważniejszych elementów wpływających na bezpieczeństwo osób przebywających na obszarach wodnych - nie tylko w kontekście utonięć, lecz także ryzyka doznania różnego rodzaju urazów ${ }^{10}$. Doświadczenie ratownika (długość stażu, liczba interwencji) wpływa na lepsze przygotowanie mentalne i wyższy poziom efektywności ratowniczej ${ }^{11}$.

\section{Polityka bezpieczeństwa na obszarach wodnych w Polsce}

System bezpieczeństwa obszarów wodnych obecnie oparty jest na ustawie z 18 sierpnia 2011 r. o bezpieczeństwie osób przebywających na obszarach wodnych, która weszła w życie 1 stycznia 2012 r. $^{12}$ Ustawę uzupełnia wiele rozporządzeń Ministra Spraw Wewnętrznych ${ }^{13}$. Wcześniej kwestie te były regulowane szczątkowo — w latach 1996-2010

10 J.A. Abraldes, J. Perez-Gomez, Assessment of risk factors for injuries on beaches, „International Journal of Aquatic Research and Education" 2009, nr 3, s. 272-283.

$11 \mathrm{~J}$. Gracz, T. Zalewski, Bezpieczna aktywność sportowo-rekreacyjna w środowisku wodnym wyznacznikiem wspótczesnej cywilizacji, „Zeszyty Naukowe Uniwersytetu Szczecińskiego” 689, 2011, nr 78, s. 97-112.

12 Ustawa z 18 sierpnia 2011 r. o bezpieczeństwie osób przebywających na obszarach wodnych, Dz.U. z 2011 r. Nr 208, poz. 1240.

${ }^{13}$ Należy tu wymienić m.in. rozporządzenie Ministra Spraw Wewnętrznych z dnia 21 czerwca 2012 r. w sprawie szkoleń w ratownictwie wodnym, Dz.U. z 2012 r. poz. 747; rozporządzenie Ministra Spraw Wewnętrznych z dnia 23 stycznia 2012 r. w sprawie minimalnych wymagań dotyczących liczby ratowników wodnych zapewniających stałą kontrolę wyznaczonego obszaru wodnego, Dz.U. z 2012 r. poz. 108. 
w ramach ustawy o kulturze fizycznej (art. 55 ust. 2,3) ${ }^{14}$, a później, w latach 2010-2011, przez zastępującą ją ustawę o sporcie ${ }^{15}$ (art. 40 ust. 2,3,4) ${ }^{16}$.

Za zapewnienie bezpieczeństwa na obszarach wodnych w nowym systemie odpowiedzialny jest tzw. zarządzający obszarem wodnym, zazwyczaj jest to właściwy miejscowo wójt (burmistrz, prezydent miasta), z wyjątkiem parków narodowych i krajobrazowych (zadanie dyrektora parku) oraz terenów, na których prowadzona jest działalność w zakresie sportu lub rekreacji (zadanie jednostki prowadzącej działalność).

Mimo wprowadzenia ustawy niezmieniony pozostał jeden $\mathrm{z}$ fundamentów systemu, jakim jest dychotomiczny podział obszarów wodnych na strzeżone i niestrzeżone, a zgodnie $\mathrm{z}$ nazewnictwem ustawowym - wyznaczone $(\mathrm{WOW})^{17}$ i niewyznaczone ${ }^{18}$. Choć z przyczyn organizacyjnych i ekonomicznych jest to zrozumiałe, to jednak może budzić wątpliwości w świetle przytaczanych danych, które wskazują, że ogromna większość utonięć ma miejsce poza wyznaczonymi obszarami wodnymi. Podział ten ma też szczególne znaczenie praktyczne, gdyż tylko WOW podlegają szczególnej ochronie ratowniczej, szerzej zdefiniowanej w ustawie i rozporządzeniach. WOW dzielą się na kąpieliska oraz tzw. miejsca wyznaczone do kąpieli - obie kategorie różnią się od siebie procedurą tworzenia, częstotliwością badań jakości wody oraz skalą zabezpieczenia ratowniczego ${ }^{19}$. Należy zaznaczyć, że prawo nie przewiduje istnienia „kąpielisk niestrzeżonych”, jakkolwiek wiele gmin opisuje je jako „miejsca tradycyjnie wykorzystywane do kąpieli”, ze względów ekonomicznych - utrzymanie kąpieliska bądź miejsca wyznaczonego do kąpieli pociąga za sobą określone obciążenia finansowe ${ }^{20}$.

Zarządzający odpowiada, poza szeroko rozumianym zapewnieniem bezpieczeństwa, za organizowanie i finansowanie działań ratowniczych na wyznaczonym obszarze wodnym. Zapewnianie bezpieczeństwa w rozumieniu ustawy polega na dokonaniu analizy zagrożeń, w tym identyfikacji miejsc, w których występuje zagrożenie, oznakowaniu i zabezpieczeniu terenów, obiektów i urządzeń przeznaczonych do pływania, kąpania się, uprawiania sportu lub rekreacji na obszarach wodnych. Oprócz tego w zakres za-

14 Ustawa o kulturze fizycznej, Dz.U. z 2010 r. Nr 127, poz. 857.

15 Ustawa o sporcie, Dz.U. z 2007 r. Nr 226, poz. 1675, tekst jednolity.

16 I. Aleksandrowicz, Zmiany w ratownictwie wodnym na gruncie ustawy o bezpieczeństwie osób przebywajacych na obszarach wodnych, „Sporty Wodne i Ratownictwo” 2011, nr 4, s. 5-11.

17 Przez wyznaczony obszar wodny rozumie się kąpielisko, miejsce wykorzystywane do kąpieli, pływalnię oraz inne obiekty dysponujące nieckami basenowymi o łącznej powierzchni powyżej $100 \mathrm{~m}^{2}$ i głębokości ponad $0,4 \mathrm{~m}$ w najgłębszym miejscu lub głębokości powyżej $1,2 \mathrm{~m}$.

18 M. Furs et al., Prawne aspekty bezpieczeństwa osób przebywających na obszarach wodnych, [w:] Edukacja dla bezpieczeństwa zdrowia publicznego. Wybrane problemy, red. B. Boniek, P. Paciorek, Bydgoszcz 2013, s. 107-117.

${ }_{19}$ Wymogi są istotnie większe dla kąpielisk. Zob. T. Czapiewski, Audyt i kategoryzacja kąpielisk w Województwie Zachodniopomorskim jako przykład aktywności na rzecz profilaktyki bezpieczeństwa, [w:] Profilaktyka bezpieczeństwa publicznego w Województwie Zachodniopomorskim, red. T. Czapiewski, M. Sikora, Szczecin 2014, s. 97-110.

20 T. Zalewski, T. Czapiewski, The impact of the processes associated with risk assessment and categorization of bathing waters on the water safety system development on Polish Baltic coast in terms of new regulations, „Journal of Coastal Research” 70, 2014, s. 551-555. 
pewniania bezpieczeństwa wchodzi prowadzenie działań profilaktycznych i edukacyjnych dotyczących bezpieczeństwa na obszarach wodnych.

Wcześniejsze regulacje, szczątkowe na poziomie ustawowym, opierały się de facto na monopolistycznej ${ }^{21}$ i autonomicznej roli WOPR. Jego pozycja formalnie ogólnopolskiego stowarzyszenia była jednak źródłem stabilności systemu, nawet w warunkach braku centralnych regulacji ${ }^{22}$. Co ważne, pierwszy projekt ustawy przygotowany przez Komisję Administracji i Spraw Wewnętrznych w 2010 r., choć dopuszczał konkurencję, w sposób wyraźny wskazywał na kluczową rolę WOPR w systemie ${ }^{23}$. Miał on być jedynym podmiotem, który organizuje oraz prowadzi szkolenia, określa uprawnienia i nadaje stopnie ratownikom wodnym, a organy administracji publicznej miały być zobowiązane do wspierania, w szczególności w formie dotacji, gotowości jednostek WOPR oraz utrzymania baz ratowniczych. Warto dodać, że w pracach nad ustawą ${ }^{24}$ często odnoszono się do głównego dokumentu diagnostycznego - raportu Najwyższej Izby Kontroli (NIK) z 2010 r., dotyczącego funkcjonowania ratownictwa wodnego ${ }^{25}$. Wskazano w nim m.in. na brak analiz w zakresie zagrożeń dla bezpieczeństwa osób pływających, kąpiących się i uprawiających sporty wodne - zarówno w skali kraju (MSW), jak i na szczeblu lokalnym (gminy ${ }^{26}$, brak kontroli stanu bezpieczeństwa nad wodą ${ }^{27}$, nieoznaczanie miejsc niebezpiecznych znakami zakazu kąpieli oraz brak jednolitego systemu łączności dla potrzeb działań ratowniczych. Zauważono też brak nadzoru ze strony MSWiA nad funkcjonowaniem specjalistycznych organizacji ratowniczych w zakresie, w jakim wywiązują się one z obowiązków nałożonych przez państwo, oraz brak rzetelnej oceny wielkości

${ }^{21}$ Przez lata jedynym podmiotem funkcjonującym w tym zakresie obok WOPR była Mazurska Służba Ratownicza, która działała tylko na ograniczonym obszarze.

22 Wedle opisywanego wcześniej rozporządzenia Ministra Spraw Wewnętrznych i Administracji z dnia 12 listopada 2002 roku organizacje specjalistyczne (WOPR, TOPR i GOPR) były obowiązane i uprawnione do organizowania pomocy oraz ratowania osób, organizowania oraz przeprowadzania szkolenia służby ratowniczej, ustalania programów kursów i szkoleń specjalistycznych z zakresu ratownictwa, nadawania stopni ratowniczych oraz określania uprawnień do prowadzenia działań ratowniczych i stwierdzania zagrożeń bezpieczeństwa osób na swoim terenie działania.

${ }^{23}$ Komisyjny projekt ustawy o bezpieczeństwie osób przebywających na obszarach wodnych z dnia 22 lipca 2010 r. przygotowany przez sejmową Komisję Administracji i Spraw Wewnętrznych, http://bit.ly /29FYyhR (dostęp: 26.02.2016).

24 Zob. szerzej S. Fundowicz, Prawo sportowe, Warszawa 2013, s. 183-189.

25 Najwyższa Izba Kontroli, Informacja o wynikach kontroli funkcjonowania ratownictwa wodnego, Warszawa 2010, s. 5-6.

26 Znamienne, że ostatecznie ustawa stworzona w oparciu o projekt przygotowany w dużej mierze w ramach MSW uregulowała tylko kwestie analiz na poziomie lokalnym, pomijając kwestię tworzenia analiz na poziomie kraju, których realizacja miała obciążać właśnie MSW.

27 Ostatecznie, wedle interpretacji samego MSW, ustawodawca nie przewidział żadnych uprawnień kontrolnych dla podmiotów uprawnionych do wykonywania ratownictwa wodnego, stąd też jako niemające podstaw prawnych traktowane są działania tych podmiotów polegające na dokonywaniu „kontroli”, „audytów”, „przeglądów” pod względem zapewnienia warunków bezpieczeństwa przez zarządzających wyznaczonymi obszarami wodnymi i sposobu realizacji przez zarządzających wyznaczonymi obszarami wodnymi obowiązków określanych ustawą; Ministerstwo Spraw Wewnętrznych, Wyjaśnienia w zakresie wykonywania ratownictwa wodnego, Warszawa 2015, s. 12. W efekcie pozbawiono głównego instrumentu jedyny podmiot realnie wykonujący kontrole stanu bezpieczeństwa nad wodą. 
i efektywności wykorzystywania środków publicznych przeznaczanych na funkcjonowanie ratownictwa wodnego w skali kraju. W opinii NIK główną przyczyną stwierdzonych nieprawidłowości był brak systemu normującego zasady funkcjonowania ratownictwa wodnego, w tym w szczególności brak określenia zakresu odpowiedzialności poszczególnych podmiotów za zapewnienie bezpieczeństwa nad wodą.

\section{Podmiot uprawniony do ratownictwa wodnego}

Jednym z podstawowych elementów ustawy było wprowadzenie kategorii podmiotu uprawnionego do wykonywania ratownictwa wodnego. Mieszczą się w niej: WOPR oraz inne podmioty, jeżeli uzyskały zgodę ministra właściwego do spraw wewnętrznych. Minister właściwy do spraw wewnętrznych udziela zgody na wniosek podmiotu w drodze decyzji administracyjnej. Aby stać się podmiotem uprawnionym, należy spełnić wiele warunków: zapewnić stan gotowości do wykonywania ratownictwa wodnego przez utrzymywanie stałych dyżurów ratowników wodnych, dysponować kadrą ratowników wodnych w liczbie niezbędnej do zapewnienia stanu gotowości; mieć siedzibę oraz niezbędny do wykonywania ratownictwa wodnego sprzęt specjalistyczny, a także środki transportu i łączności. Warunki te, określone w sposób ogólny (jaki sprzęt specjalistyczny i jaka liczba ratowników są „niezbędne”?), nie zostały doprecyzowane w żadnym $\mathrm{z}$ aktów wykonawczych, co od razu wskazywało, że główną rolę w interpretacji tych przepisów będzie odgrywało ministerstwo. Praktyka przyjęta przez ten organ okazała się bardzo liberalna - według stanu na dzień 1 marca $2016 \mathrm{r}^{28}$ wykaz podmiotów uprawnionych do wykonywania ratownictwa wodnego obejmuje 111 podmiotów ${ }^{29}$. Przeprowadzone wywiady wskazały, że brakuje weryfikacji i nadzoru nad tymi podmiotami, w dużym stopniu dlatego, że brakuje zasobów po stronie ministerstwa - w szczególności kadr dysponujących wiedzą ekspercką w tej dziedzinie. Ważną rolę odgrywa też obawa przed kontrolą sądową (odwołanie od decyzji administracyjnej) wobec ogólnikowości regulacji. Duża liczba podmiotów, które uzyskały zgodę, ich różna proweniencja, nieporównywalny standard kompetencji, krótki rzeczywisty okres działania - często w rzeczywistości zawężony wyłącznie do wakacji - dodatkowo utrudnia administracji rządowej sprawny nadzór, zwłaszcza że uprawnienia nadzorcze zostały ograniczone do MSW - szczebla centralnego - bez uwzględnienia roli wojewody i podległej mu administracji. Faktem jest, jak wskazują Wojciech Wiesner i Bogusław Kowalewski ${ }^{30}$, że podmioty uprawnione kierowane są $\mathrm{w}$ większości przez osoby fizyczne ukształtowane przez

${ }^{28} \mathrm{http}: / /$ bit.ly/29FYTRZ (dostęp: 10.03.2016).

29 W tym takie jak: Romuald Kowalski Zakład Handlowo-Usługowy „Romulus” z Nowogardu, Bud-Blok Karol Wasielewski ze Szczecina, Sport Mega Marketing Sp. z o.o. z Poznania, Rock s.c. Joanna Matusiak Tomasz Czuper z Gliwic, Inwestycje Kapitałowe „Profit” Piotr Kuc z Bolechowic, Dariusz Baran Firma Handlowo-Usługowa „Mika” z Wałcza czy Klub Tenisowy „SMECZ” Ratownictwo Wodne Sandomierz Grupa Patrolowo Interwencyjna z Sandomierza.

${ }^{30}$ W. Wiesner, B. Kowalewski, Charakterystyka podmiotów odpowiedzialnych za ratownictwo wodne w Polsce, [w:] Stan, perspektywy i rozwój ratownictwa..., s. 12. 
WOPR (ratownicy i instruktorzy WOPR). Trudno jednak wyprowadzić z tego wniosek, że musi to zapewniać wysoki standard prowadzonej przez podmiot aktywności. Co interesujące, $w$ rejestrze podmiotów uprawnionych do wykonywania ratownictwa górskiego do dziś figurują ciągle tylko dwa podmioty o historycznym znaczeniu: GOPR i TOPR.

Obecnie nadal brakuje zbiorczych danych dotyczących udziału podmiotów innych niż WOPR w zapewnieniu bezpieczeństwa wodnego. Analiza przeprowadzona przez autora w sezonie kąpielowym w 2015 r. w województwie zachodniopomorskim wykazała, że podmioty prywatne zapewniały ochronę ratowniczą na 16,8\% całości WOW, lecz aż $28,2 \%$ ze wszystkich kąpielisk.

Zgodnie $\mathrm{z}$ art. 14 ust. 1 ustawy podmioty uprawnione do wykonywania ratownictwa wodnego nie tylko organizują, kierują, koordynują i bezpośrednio prowadzą działania ratownicze w ramach ratownictwa wodnego (o czym była mowa powyżej), lecz także mają obowiązek prowadzenia działalności profilaktycznej i edukacyjnej dotyczącej bezpieczeństwa na obszarach wodnych oraz ujawniania zagrożenia w zakresie bezpieczeństwa osób przebywających na obszarach wodnych i przekazywania informacji o tych zagrożeniach właściwej radzie gminy. Dodatkowo, jak wspomniano wcześniej, obligatoryjne jest utrzymywanie przez podmiot stałych dyżurów ratowników wodnych. Obowiązkowi temu podlega każdy z podmiotów wpisanych do rejestru, mimo że większość z nich nie otrzymuje na to żadnych środków publicznych. Zarządzający obszarem wodnym finansuje wybranemu podmiotowi tylko realizację działań ratowniczych.

Jeżeli zarządzający zlecają działania ratownicze podmiotowi uprawnionemu, nie ingerują zazwyczaj w sposób realizacji obowiązków przez zleceniobiorcę, zakładając, że została w ten sposób przeniesiona odpowiedzialność za ewentualne nieprawidłowości. Ustawa nie narzuca również obowiązku regularnej weryfikacji umiejętności i wiedzy ratownika, pozostawiając to $\mathrm{w}$ gestii podmiotów, a większość $\mathrm{z}$ nich, odmiennie niż WOPR, takich działań nie prowadzi. Nierzadka jest też inna praktyka - podmioty zarządzające, np. basenem, nie zlecają zadania podmiotom uprawnionym do ratownictwa wodnego, tylko same bezpośrednio zatrudniają ratowników.

Według nowej ustawy organizowanie i prowadzenie szkoleń w zakresie ratownictwa wodnego jest uprawnieniem podmiotów mających zgodę na wykonywanie ratownictwa wodnego, wydaną przez ministra właściwego do spraw wewnętrznych. Zajęcia teoretyczne i praktyczne w ramach szkolenia ratowników wodnych może, oprócz instruktorów, prowadzić także osoba będąca ratownikiem wodnym, mająca co najmniej trzyletnie doświadczenie $\mathrm{w}$ wykonywaniu działań ratowniczych, aktualną wiedzę i umiejętności z zakresu objętego ramowym programem oraz przygotowanie pedagogiczne określone odrębnymi przepisami ${ }^{31}$. W przeprowadzonych wywiadach często pojawiała się opinia, że wobec braku właściwego nadzoru prowadzone przez wiele podmiotów szkolenia nie spełniają kryteriów wyznaczonych przez przepisy, nawet jeśli chodzi o liczbę realnie przeprowadzonych godzin szkolenia. Podobnie fikcyjny charakter mają często stałe dy-

31 Tak liberalna konstrukcja przepisu często spotykała się z postulatem nowelizacji ze strony środowisk WOPR (do dziś niezrealizowanym). Zob. Nowoczesne zarządzanie bezpieczeństwem na wodach przygranicznych Polski i Niemiec, załącznik 1. Propozycje zmian, red. T. Zalewski, Szczecin 2013, s. 135. 
żury ratownicze, których realizację deklarują podmioty uprawnione. Nawet analizując samą treść wymogów zdefiniowanych przez akty prawne, można zauważyć, że obecnie egzaminy są mniej wymagające niż te przed 2009 rokiem czy w latach 2009-2011 32 .

Liczba funkcjonujących w Polsce kąpielisk w latach 2012-2014 zmalała z 221 do 202, tj. o 8,6\%, a liczba miejsc wykorzystywanych do kąpieli - z 848 do 459, tj. o 45,9\%33. Jednocześnie z 11 do 7 spadła liczba kąpielisk w Polsce, których stan sanitarny oceniono negatywnie, oraz z 21 do 29 wzrosła liczba kąpielisk wyróżnionych uznawanym w świecie znakiem Błękitnej Flagi. Ponadto w połowie badanych przez NIK w 2015 r. gmin nie zapewniono bezpieczeństwa osób przebywających na obszarach wodnych gminy poprzez oznakowanie i zwiększenie nadzoru w miejscach zidentyfikowanych jako niebezpieczne do pływania, kąpania się, uprawiania sportu lub rekreacji, a w ponad 20\% badanych gmin nie zapewniono bezpieczeństwa osób w miejscach wykorzystywanych do kąpieli poprzez wymagane ich oznakowanie, zatrudnienie ratowników wodnych oraz wyposażenie w sprzęt ratunkowy, pomocniczy i medyczny ${ }^{34}$. Na terenie województwa zachodniopomorskiego w 2015 r. spośród 112 wyznaczonych obszarów wodnych na 17 nie było żadnej ochrony ratowniczej ${ }^{35}$. W wielu gminach bez wyznaczonych WOW zarządzający obszarem wodnym nie wie lub nie chce wiedzieć o swoich obowiązkach dotyczących zapewniania bezpieczeństwa na innych obszarach wodnych. Nie jest też do końca jasne, kto ma być podmiotem wiodącym przy realizacji analizy zagrożeń - gmina, podmiot uprawiony do wykonywania ratownictwa czy policja.

Nierzadkie są takie negatywne praktyki, jak: współorganizowanie i prowadzenie szkoleń z zakresu ratownictwa wodnego przez podmioty, z których jeden nie ma zgody na wykonywanie ratownictwa wodnego czy „użyczanie” zgody na wykonywanie ratownictwa wodnego polegające na zawieraniu porozumień o współpracy ${ }^{36}$. Do dodatkowych okoliczności utrudniających funkcjonowanie systemu ratownictwa należy zaliczyć emigrację zarobkową ratowników.

Do dziś w Polsce nie wypracowano także ogólnokrajowego programu profilaktyki utonięć na skalę kraju. Dominują projekty jednorazowe, głównie o zasięgu lokalnym, choć i tutaj widać mniejszą intensywnośćc ${ }^{37}$. Można też wspomnieć o kryzysie idei woluntarystycznej $^{38}$ narastającym w opisywanych realiach (deregulacja, słabnąca pozycja i wewnętrzne skonfliktowanie WOPR).

32 A. Ostrowski et al., Szkolenie ratowników wodnych na tle zmieniających się uwarunkowań prawnych, [w:] Stan, perspektywy i rozwój ratownictwa..., s. 127.

33 Najwyższa Izba Kontroli, Informacja o wynikach kontroli. Organizacja i utrzymanie kąpielisk oraz miejsc wykorzystywanych do kapieli, Warszawa 2015, s. 10.

${ }^{34}$ Ibidem, s. 9.

35 Stan bezpieczeństwa wodnego w województwie zachodniopomorskim w 2015 roku, Szczecin 2015, s. 7.

36 Odpowiedź Stanisława Rakoczego - podsekretarza stanu w Ministerstwie Spraw Wewnętrznych na interpelację nr $9924 \mathrm{w}$ sprawie podmiotów uprawnionych do wykonywania czynności w ramach ratownictwa wodnego z dnia 22 listopada 2012 r.

37 J. Telak, Propozycja kierunku rozwoju systemu szkolenia Państwowej Straży Pożarnej w zakresie ratownictwa wodnego, „Zeszyty Naukowe SGSP” 52, 2014, nr 4, s. 58.

38 „Praca ratownika z pewnością w pełnym znaczeniu tego słowa nie jest wolontariatem, lecz można przyjąć, że jest to praca o charakterze woluntarystycznym, bądź nosząca wiele cech właściwych wolontariatowi”. 


\section{Procesy polityki publicznej}

Warto w tym miejscu uzupełnić analizę o odniesienie się do kilku istotnych pojęć z obszaru teorii polityki publicznej. W procesie kształtowania polityki ważną rolę odgrywają tzw. wydarzenia skupiające (focusing events) - rzadkie, o ograniczonym czasie trwania, mające szkodliwy przebieg i wskazujące na istnienie problemu, który wywołuje istotną reakcję władz publicznych zgodnie z oczekiwaniami opinii publicznej lub mediów ${ }^{39}$. Katastrofa o masowej skali wzbudza zainteresowanie mediów i opinii publicznej, a w konsekwencji tworzy przekonanie o potrzebie istotnych działań po stronie polityków. Utonięcia mają charakter jednostkowy, rzadko więc przyciągają zainteresowanie mediów, nie są też traktowane jako wiadomości najwyższej wagi, utrzymujące się na pierwszych stronach gazet przez wiele dni, jak np. katastrofy lotnicze czy zabójstwa. Wedle teorii przerywanej równowagi ${ }^{40}$ mniej istotne obszary polityki publicznej rzadko trafiają do systemu politycznego skali makro. Władze polityczne zajmują się najczęściej jedną, co najwyżej kilkoma kwestiami problemowymi jednocześnie. Muszą to być w takiej sytuacji kwestie wielkiej wagi, o najwyższej pozycji w politycznej agendzie ${ }^{41}$. Trudno przy tworzeniu opisywanej ustawy znaleźć moment, w którym bodziec o konieczności tworzenia nowej ustawy wypłynął ze strony systemu makro. Jej powstanie było prawdopodobnie refleksem prac nad ustawą o ratownictwie górskim - nie po raz pierwszy ratownictwo wodne podążało tą drogą ${ }^{42}$. W przygotowaniu ustawy o ratownictwie górskim główną rolę odegrał Piotr van der Coghen ${ }^{43}$, ratownik górski, a także przez dwie kadencje poseł partii rządzącej. Projekt ustawy dotyczącej ratownictwa wodnego powstał w Ministerstwie Spraw Wewnętrznych przy bardzo ograniczonym wpływie osłabionego WOPR. Jak pokazują przeprowadzone wywiady, proces legislacyjny w odniesieniu do ustawy i rozporządzeń wykonawczych w odczuciu wielu jego uczestników był chaotyczny i niejasny, natomiast udział podmiotów pozarządowych - ograniczony. Brakowało realnej współpracy i wymiany myśli, a tryb pracy był pospieszny (starano się usilnie zakończyć je przed końcem VI kadencji Sejmu). Potwierdza to tezę stawianą przez Agnieszkę

Taki charakter w przeszłości miał w szczególności pierwszy etap - młodszego ratownika wodnego, który można było uzyskać w wieku 12 lat, a przy braku możliwości zarobkowania jest „swoistym testerem wyposażenia emocjonalnego jednostki, mającego charakter woluntarystyczny". D. Skalski, System szkolenia ratowników wodnych a ich sprawność fizyczna w świetle standardów bezpieczeństwa i systemów zarządzania (rozprawa doktorska), Gdańsk 2012, s. 82, 131.

39 Zob. szerzej T. Birkland, After Disaster: Agenda-setting, Public Policy, and Focusing Events, Waszyngton 1997; idem, Lessons of Disaster. Policy Change after Catastrophic Events, Waszyngton 2007.

40 J. True, B. Jones, F. Baumgartner, Punctuated equilibrium theory. Explaining stability and change in public policymaking, [w:] Theories of the Policy Process, red. P. Sabatier, Boulder 2007, s. 156-159.

41 B. Jones, Reconceiving Decision-Making in Democratic Politics: Attention, Choice and Public Policy, Chicago 1994.

42 WOPR był tworzony nawet na wzór GOPR. Zob. J. Burski, Wodne Ochotnicze Pogotowie Ratunkowe 1962-2012, Warszawa 2012, s. 11.

43 Sam opisuje się na swojej stronie internetowej jako „autor, uchwalonej jednogłośnie przez sejm RP, pierwszej w historii polskiego parlamentu ustawy o bezpieczeństwie i ratownictwie w górach i na zorganizowanych terenach narciarskich", http://www.piotrvandercoghen.pl/pl/ (dostęp: 23.01.2016). 
Dudzińską, że polską praktykę legislacyjną można określić jako system operacyjnie (a nawet kognitywnie) zamknięty - jego wytwory pochodzą wyłącznie z wewnętrznego obiegu komunikacyjnego ${ }^{44}$.

Deregulacja to, za Słownikiem języka polskiego, unieważnienie przepisów prawnych uznanych za zbędne, regulujących jakiś rodzaj aktywności, lecz także wycofywanie się państwa z regulowania wybranych dziedzin życia społecznego lub gospodarczego ${ }^{45}$. Warto też nawiązać tutaj do rozróżnienia na deregulację gramatyczną, kiedy to mamy mniej regulacji, w tym mniej regulatorów ustawowych, a także krótszy akt prawny, oraz deregulację funkcjonalną, w której istotą jest regulowanie materii w inny sposób, $\mathrm{w}$ oparciu o inne przesłanki, tak aby zmiany legislacyjne uwalniały w pewnym zakresie, a więc odregulowywały system ${ }^{46}$.

W badanym obszarze obecne są regulatory takie jak ustawy, rozporządzenia czy statuty organizacji ratowniczych, a także, przynajmniej w założeniu, mechanizmy reglamentacyjne związanie $\mathrm{z}$ udzielaniem zgody na wykonywanie ratownictwa wodnego oraz związane z tym działania nadzorcze. Można jednak w tym przypadku dostrzec, jak silny jest potencjał deregulacyjny rynku. Choć istnieją poważne wątpliwości wobec tezy o prewencyjnej roli aktu prawnego, który pozwalałby na wykluczenie lub istotne zminimalizowanie wszystkich patologii, to jednocześnie nie mniej wątpliwe w kwestiach dotyczących bezpieczeństwa jest przyjęcie zasady zaufania i pomocniczości jako podstawy zapewniania jakości ${ }^{47}$. W ocenie polityki sektorowej zawsze trzeba wziąć pod uwagę, że efekty na wyjściu mogą różnić się od intencji decydenta. Zarówno w uzasadnieniu pierwszego projektu ustawy, jak i podczas prac komisyjnych dominowały argumenty dotyczące podnoszenia poziomu bezpieczeństwa ${ }^{48}$. W praktyce głównym elementem systemu stała się konkurencja cenowa pomiędzy podmiotami uprawnionymi, kiedy zarządzający obszarem często nie jest zainteresowany szukaniem usługi dobrej jakości, a jedynym kryterium jest najniższa cena w granicach usługi deklarowanej jako wypełniającej wymogi prawne. Trudno zrozumieć intencję ustawodawcy, zwłaszcza w świetle wypowiedzi rzecznik MSW Małgorzaty Woźniak, która pogarszające się statystyki utonięć podsumowała stwierdzeniem, że „nawet najlepsze przepisy nie pomogą, jeżeli ludzie będą wybierać miejsca niestrzeżone i lekceważyć zagrożenia" ${ }^{\prime 9}$. Warto w tym miejscu przytoczyć słuszną opinię, że nadrzędnym celem zmian „powinno być jednak

44 A. Dudzińska, System polityczny. Socjologiczna analiza procesu legislacyjnego, Warszawa 2015, s. 118-133.

45 Stownik języka polskiego PWN, red. L. Drabik, E. Sobol, Warszawa 2013.

46 J. Woźnicki, Idee deregulacji, [w:] Deregulacja w systemie szkolnictwa wyższego, red. J. Woźnicki, Warszawa 2015, s. 63-64.

47 Ibidem, s. 76-78.

48 Choć już podczas dyskusji w ramach posiedzenia Komisji Spraw Wewnętrznych podsumowującej dwa lata po wejściu w życie ustawy Dyrektor Departamentu Porządku i Bezpieczeństwa Wewnętrznego Najwyższej Izby Kontroli Marek Bieńkowski stwierdził: „żaden z moich przedmówców nie zakwestionował podstawowej zasady wynikającej z tej ustawy, a mianowicie zasady zakładającej konkurencyjność". Kancelaria Sejmu, Petny zapis przebiegu posiedzenia Komisji Spraw Wewnętrznych (nr 125) z dnia 9 stycznia 2014 r., s. 27.

49 P. Szymaniak, Bezpieczeństwo nad wodą: Zliberalizowane przepisy nie uratowały tonących, „Dziennik Gazeta Prawna” 29.07.2015. 
zmniejszenie liczby wypadków utonięć oraz wzrost poczucia bezpieczeństwa wśród osób wypoczywających nad wodą. Takie założenie ma także znaczenie aksjologiczne wyznaczone przez wartość ludzkiego życia" 50 .

Różnice w stopniu uporządkowania i kontroli nad reżimem ochrony osób przebywających na obszarach wodnych a reżimem ochrony jakości wody są wyraźnie dostrzegalne $^{51}$. Ten ostatni wyróżnia chociażby istnienie silnej struktury państwowej w postaci stacji sanitarno-epidemiologicznych. Warto dodać, że system ochrony jakości wód w Polsce powstał w wyniku adaptacji do przepisów europejskich - dyrektywy 2006/7/WE Parlamentu Europejskiego i Rady z dnia 15 lutego 2006 r. dotyczącej zarządzania jakością wody w kąpieliskach. Rafał Riedel wprost pisał o ochronie wód jako obszarze, na którym wystąpiła „presja europeizacyjna” w postaci importu norm europejskich i dostępności środków z funduszy unijnych ${ }^{52}$.

Rosnące wymogi wobec tworzenia kąpielisk i miejsc wykorzystywanych do kąpieli, a jednocześnie brak wskazania, kiedy tworzenie takich obszarów jest konieczne, powoduje naturalną reakcję - zmniejszenie liczby kąpielisk i miejsc wykorzystywanych do kąpieli (zwłaszcza tych ostatnich). Jednocześnie rośnie liczba kąpielisk odznaczonych prestiżową Błękitną Flagą. Obserwację taką potwierdza analiza stanu bezpieczeństwa wodnego w województwie zachodniopomorskim w 2015 r., która wskazuje, że regularnie podnosi się poziom bezpieczeństwa, lecz wyłącznie na kąpieliskach morskich ${ }^{53}$. Możemy więc mówić o różnicowaniu bezpieczeństwa na obszarach wodnych - bastionach bezpieczeństwa w bogatych gminach nadmorskich — i obniżaniu poziomu bezpieczeństwa na pozostałych obszarach (które stanowią większość).

Wobec słabości nadzoru ze strony administracji państwa być może dopiero aktywność sądów zmobilizuje gminy do działania. Mowa tu o powództwach cywilnych lub nawet procesach karnych, gdy doszło do utraty życia lub zdrowia na obszarach wodnych, na których gmina nie podjęła wcześniej aktywności, do których formalnie jest obowiązana, takich jak np. analiza zagrożeń lub oznakowanie miejsc niebezpiecznych.

\section{Podsumowanie}

Efektem wprowadzenia ustawy i aktów wykonawczych, a w szczególności przyjętej praktyki wykładni przepisów przez ministerstwo, stały się deregulacja i komercjalizacja badanej dziedziny polityki publicznej. Organom państwa brakuje odpowiednich zasobów do realizowania funkcji nadzorczej lub choćby koordynującej. Widoczne jest to w szczególności w trzech kwestiach: działalności nowo powstałych podmiotów uprawnionych

50 W. Wiesner, B. Kowalewski, Analiza zabezpieczenia ratowniczego akwenów na terenie Olsztyna, „Polish Hyperbaric Research" 52, 2015, nr 3, s. 60.

51 M. Sikora, Proces kapieliskowy w zakresie tworzenia systemu monitoringu oraz informowania o jakości wody na obszarach kąpielisk śródlądowych Województwa Zachodniopomorskiego, [w:] Profilaktyka bezpieczeństwa publicznego..., s. 71-72.

52 R. Riedel, Europeizacja polityk publicznych, „Wrocławskie Studia Politologiczne” 2015, nr 18, s. 67.

53 Stan bezpieczeństwa wodnego w województwie zachodniopomorskim w 2015 roku, Szczecin 2015, s. 12. 
do wykonywania ratownictwa wodnego, zapewnieniu bezpieczeństwa przez zarządzającego obszarem wodnym (najczęściej podmiotem tym jest gmina) oraz działalności szkoleniowej instruktorów spoza WOPR. Sytuacji nie poprawia często nieczytelna demarkacja obowiązków pomiędzy podmiotami publicznymi - samorządami różnych szczebli, policją, stacjami sanitarno-epidemiologicznymi, strażą pożarną oraz ministerstwami.

Ustawa przeniosła obowiązki bez tworzenia spójnego systemu finansowania i wprowadziła system konkurencji cenowej bez sprawnego systemu kontroli przestrzegania wymogów przez podmioty uprawnione i zarządzających obszarami wodnymi. Rosnący udział podmiotów prywatnych - osób fizycznych czy spółek cywilnych działających dla zysku — pozwala mówić o zjawisku komercjalizacji. Deregulacja i komercjalizacja mieszczą się w neoliberalnym trendzie modelowania polityki publicznej. Jest to też przykład deregulacji de facto, kiedy instytucje państwa wycofują się realnie z działalności lub nadzoru nad pewnym obszarem funkcjonowania społeczeństwa i deregulacji funkcjonalnej, gdzie mimo wprowadzenia nowej regulacji uwolniono i odregulowano system w pewnym zakresie. Zmiany te przyniosły obniżenie kosztów po stronie zarządzających (gmin), lecz jednocześnie można zaryzykować globalną ocenę, że doszło do obniżenia poziomu bezpieczeństwa osób przebywających na obszarach wodnych.

Przyjęte współcześnie na świecie kierunki efektywnej profilaktyki utonięć, zarysowane precyzyjnie w raporcie WHO, rozmijają się kompletnie z mechanizmami i skutkami implementacji opisywanej ustawy. Trudno też w obecnym systemie dostrzec spójność z ustaleniami NIK, które stały się jedną z podstaw do prac nad ustawą. Brakuje narodowej strategii, której podstawowym elementem powinna być zorganizowana działalność profilaktyczna, ponieważ nadzieję, że lukę wypełnią podmioty prywatne pozbawione publicznego finansowania, można określić jako naiwną. Ustawa nie jest przejawem żadnej spójnej koncepcji bezpieczeństwa obszarów wodnych i trudno na jej podstawie odtworzyć cele ustawodawcy. W tej chwili najbardziej jednak brakuje pełnej i rzetelnej ewaluacji skutków jej implementacji - nie przeprowadziły jej do końca 2015 r. ani Ministerstwo, ani Sejm.

\section{Bibliografia}

Abraldes J.A., Perez-Gomez J., Assessment of risk factors for injuries on beaches, „International Journal of Aquatic Research and Education" 3, 2009.

Aleksandrowicz I., Zmiany w ratownictwie wodnym na gruncie ustawy o bezpieczeństwie osób przebywajacych na obszarach wodnych, „Sporty Wodne i Ratownictwo” 2011, nr 4.

Birkland T., After Disaster: Agenda-setting, Public Policy, and Focusing Events, Waszyngton 1997.

Birkland T., Lessons of Disaster. Policy Change after Catastrophic Events, Waszyngton 2007.

Brudnicki P., Turbokapitalizm - szanse i zagrożenia rozwoju $w$ warunkach gospodarki wysoko rozwiniętej, „Kwartalnik Kolegium Ekonomiczno-Społecznego Studia i Prace” 2013, nr 4.

Chrabąszcz R., Zawicki M., Nauki o polityce publicznej, [w:] Wprowadzenie do nauk o polityce publicznej, red. M. Zawicki, Warszawa 2013.

Czapiewski T., Audyt i kategoryzacja kąielisk $w$ Województwie Zachodniopomorskim jako przykład aktywności na rzecz profilaktyki bezpieczeństwa, [w:] Profilaktyka bezpieczeństwa publicznego $w$ Województwie Zachodniopomorskim, red. T. Czapiewski, M. Sikora, Szczecin 2014. 
Czapiewski T., Samorząd Województwa jako uczestnik systemu bezpieczeństwa wodnego, [w:] Bezpieczeństwo wewnętrzne w województwie zachodniopomorskim, red. T. Czapiewski, M. Sikora, Szczecin 2012.

Dudzińska A., System polityczny. Socjologiczna analiza procesu legislacyjnego, Warszawa 2015.

Fundowicz S., Prawo sportowe, Warszawa 2013.

Furs M. et al., Prawne aspekty bezpieczeństwa osób przebywajacych na obszarach wodnych, [w:] Edukacja dla bezpieczeństwa zdrowia publicznego. Wybrane problemy, B. Boniek, P. Paciorek, Bydgoszcz 2013.

Gracz J., Zalewski T., Bezpieczna aktywność sportowo-rekreacyjna w środowisku wodnym wyznacznikiem współczesnej cywilizacji, „Zeszyty Naukowe Uniwersytetu Szczecińskiego” 689, 2011, nr 78.

Halik R. et al., Wypadkowe utonięcia w Polsce w latach 2000-2012, „Przegląd Epidemiologiczny” 2014, nr 68.

Jones B., Reconceiving Decision-Making in Democratic Politics: Attention, Choice and Public Policy, Chicago 1994.

Kancelaria Sejmu, Petny zapis przebiegu posiedzenia Komisji Spraw Wewnętrznych (nr 125) z dnia 9 stycznia $2014 r$.

Komisyjny projekt ustawy o bezpieczeństwie osób przebywających na obszarach wodnych z 22 lipca $2010 \mathrm{r}$. przygotowany przez sejmową Komisję Administracji i Spraw Wewnętrznych.

Ministerstwo Spraw Wewnętrznych, Wyjaśnienia w zakresie wykonywania ratownictwa wodnego, Warszawa 2015.

Najwyższa Izba Kontroli, Informacja o wynikach kontroli funkcjonowania ratownictwa wodnego, Warszawa 2010.

Najwyższa Izba Kontroli, Informacja o wynikach kontroli. Organizacja i utrzymanie kapielisk oraz miejsc wykorzystywanych do kapieli, Warszawa 2015.

Nowoczesne zarzadzanie bezpieczeństwem na wodach przygranicznych Polski i Niemiec, załącznik 1. Propozycje zmian, red. T. Zalewski, Szczecin 2013.

Ostrowski A. et al., Szkolenie ratowników wodnych na tle zmieniających się uwarunkowań prawnych, [w:] Stan, perspektywy i rozwój ratownictwa, kultury fizycznej i sportu w XXI wieku, red. M. Napierała, A. Skaliy, t. 1. Ratownictwo, Bydgoszcz 2015.

Riedel R., Europeizacja polityk publicznych, „Wrocławskie Studia Politologiczne” 2015, nr 18.

Sikora M., Proces kapieliskowy w zakresie tworzenia systemu monitoringu oraz informowania o jakości wody na obszarach kąpielisk śródlądowych Województwa Zachodniopomorskiego, [w:] Profilaktyka bezpieczeństwa publicznego w Województwie Zachodniopomorskim, red. T. Czapiewski, M. Sikora, Szczecin 2014.

Skalski D., System szkolenia ratowników wodnych a ich sprawność fizyczna w świetle standardów bezpieczeństwa i systemów zarządzania, Gdańsk 2012.

Słownik języka polskiego PWN, red. L. Drabik, E. Sobol, Warszawa 2013.

Stan bezpieczeństwa wodnego w województwie zachodniopomorskim w 2015 roku, Szczecin 2015.

Stanula A. et al., Ilościowa oraz przyczynowa analiza wypadków utonięć w Polsce w latach 2005-2014, [w:] Stan, perspektywy i rozwój ratownictwa, kultury fizycznej i sportu w XXI wieku. red. M. Napierała, A. Skaliy, t. 1. Ratownictwo, Bydgoszcz 2015.

Telak J., Propozycja kierunku rozwoju systemu szkolenia Państwowej Straży Pożarnej w zakresie ratownictwa wodnego, „Zeszyty Naukowe SGSP” 52, 2014, nr 4.

True J., Jones B., Baumgartner F., Punctuated equilibrium theory. Explaining stability and change in public policymaking, [w:] Theories of the Policy Process, red. P. Sabatier, Boulder 2007.

Wiesner W., Kowalewski B., Analiza zabezpieczenia ratowniczego akwenów na terenie Olsztyna, „Polish Hyperbaric Research" 52, 2015, nr 3.

Wiesner W., Kowalewski B., Charakterystyka podmiotów odpowiedzialnych za ratownictwo wodne w Polsce, [w:] Stan, perspektywy i rozwój ratownictwa, kultury fizycznej i sportu w XXI wieku, red. M. Napierała, A. Skaliy, t. 1. Ratownictwo, Bydgoszcz 2015.

Woźnicki J., Idee deregulacji, [w:] Deregulacja w systemie szkolnictwa wyższego, red. J. Woźnicki, Warszawa 2015. 
Zalewski T., Proces rozwoju systemu bezpieczeństwa wodnego $w$ województwie zachodniopomorskim $w$ latach 2009-2012, [w:] Bezpieczeństwo wewnętrzne w województwie zachodniopomorskim, red. T. Czapiewski, M. Sikora, Szczecin 2012.

Zalewski T., Czapiewski T., The impact of the processes associated with risk assessment and categorization of bathing waters on the water safety system development on Polish Baltic coast in terms of new regulations, „Journal of Coastal Research” 70, 2014.

\section{Źródła internetowe}

fakty.nl.

mojaholandia.nl.

mswia.gov.pl.

piotrvandercoghen.pl/pl.

policja.pl.

wsse.szczecin.pl.

\section{To regulate in order to deregulate. Water safety policy in Poland}

Keywords: public policy, internal security, policy process, drownings

\section{Summary}

The aim of this article is to analyze the reform of the water safety system in Poland and the functioning of this public policy domain after four full years after passing of the new law. The author states that the deregulation and commercialization are the main effects of the reform, and are in particular caused by adopted practice of interpretation of the rules by the ministry. State authorities lack adequate resources to carry out the supervisory or even coordinating functions. The new act transferred responsibilities without creating a coherent system of financing and introduced a system of price competition without effective system for checking regulatory compliance. The growing share of private actors - individuals or civil law partnerships operating for leads to the conclusion about commercialization. The adopted regulations are not in compliance with modern world trends of effective prevention against drowning, precisely outlined in the WHO report. 